Cornell Law Library

Scholarship@Cornell Law: A Digital Repository

Cornell Law Faculty Publications

Faculty Scholarship

$1-1-1993$

\title{
Artifactions: The Battle over the National Endowment for the Arts
}

Michael C. Dorf

Cornell Law School, michaeldorf@cornell.edu

Follow this and additional works at: http://scholarship.law.cornell.edu/facpub

Part of the Law and Society Commons

\section{Recommended Citation}

Dorf, Michael C., "Artifactions: The Battle over the National Endowment for the Arts" (1993). Cornell Law Faculty Publications. Paper 121.

http://scholarship.law.cornell.edu/facpub/121

This Article is brought to you for free and open access by the Faculty Scholarship at Scholarship@Cornell Law: A Digital Repository. It has been accepted for inclusion in Cornell Law Faculty Publications by an authorized administrator of Scholarship@Cornell Law: A Digital Repository. For more information, please contact jmp8@cornell.edu. 


\section{Michael C. Dorf}
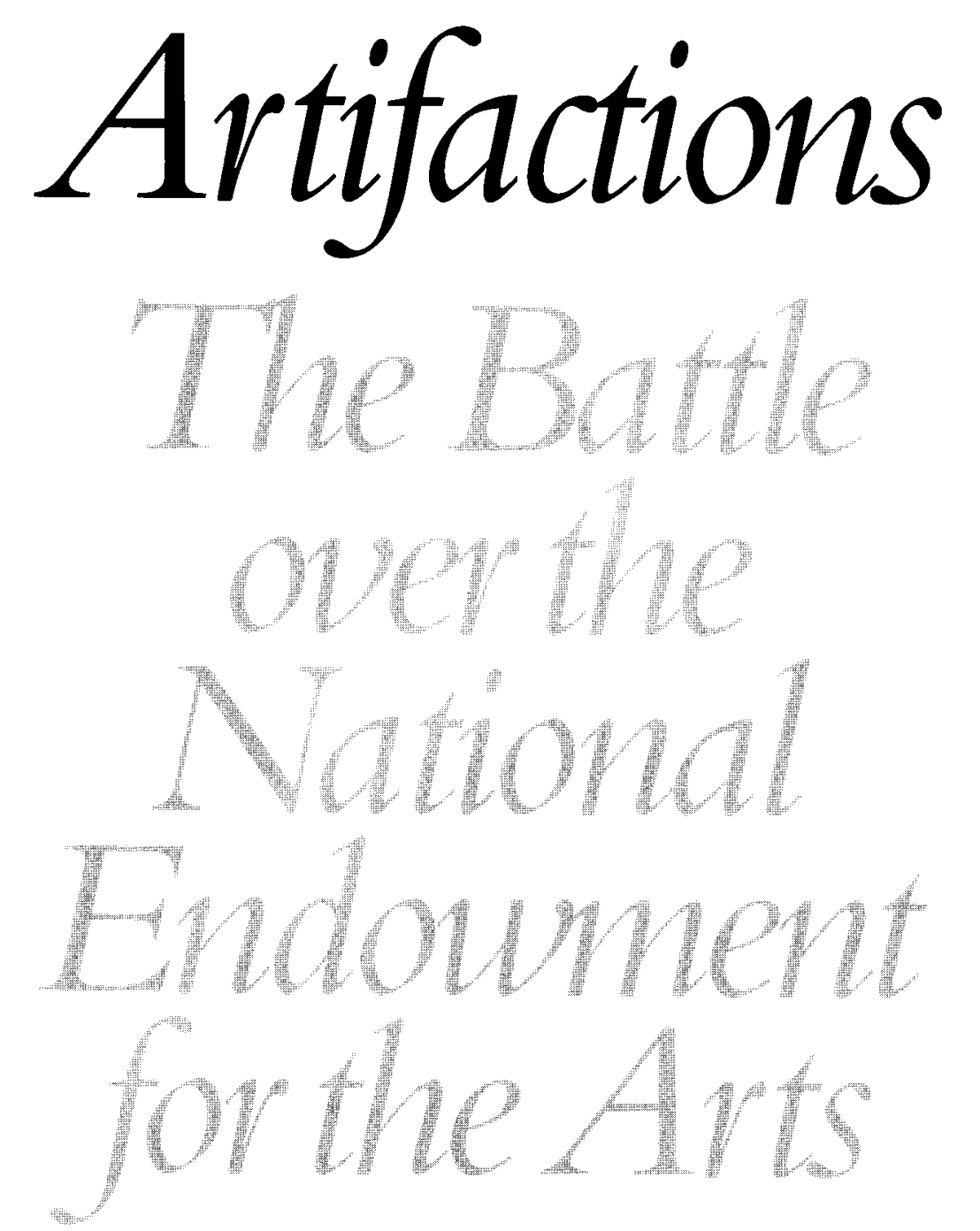

Michael C. Dorf, partner in the Chicago law firm of Schuyler, Roche E Zwirner, consults nationally on arts policy and advocacy isstes. $s$ the Republicans stumped New Hampshire last spring, candidato Patrick Buchanan lashed out at the National Endowment for the Arts for supporting a counter-culture aimed at eradicating Christian values. A war, he charged, was being waged "for the soul of America," and in that war, the Bush administration had become a "conscientious objector." The solution, as Buchanan saw it, was to "close, padlock, and fumigate" the NEA. In response, President Bush fired NEA Chairman John Frohnmayer and turned the agency over to those who, while "saving" it, may be doing it more damage than a padlock ever could.

The NEA had drawn Buchanan's wrath for, among other things, awarding a grant to the Washington, D.C., Corcoran Gallery of Art for an exhibit that included a series of photographs by Robert Mapplethorpe depicting sadomasochistic and homoerotic activities. Accordingly, in one of her first acts as acting chairwoman of the NEA after succeeding Frohnmayer last May, Anne-Imelda Radice vetoed grants for two sexually explicit art exhibitions requested by the Massachusetts Institute of Technology and Virginia Commonwealth University. Both had been recommended for funding by NEA expert advisory panels and the 26-member National Council on the Arts. Radice stated in interviews with the Washington Post and the New York Times that she took the actions "to preserve the arts endowment; that's my goal. If the agency survives, people will say, 'I didn't agree with her, but thank God the endowment's still here."'

Radice's actions represent a radical shift in NEA policy, which has been that arts grants are to be judged by artists and art historians, not government officials. If, as Radice states, the agency's goal has become its own survival through the suppression of controversy and experiment, the time has come - and the election of Bill Clinton presents the obvious opportunity - to reevaluate the NEA's philosophy, purpose, and perhaps even its existence.

The National Endowment for the Arts was established by Congress in 1965, along with its companion agency, the National Endowment for the Humanities, with a declaration that "while no government can call a great artist or scholar into existence," it can and should help sustain "a climate encouraging freedom of thought, imagination, and inquiry" and also provide material support encouraging "the release of this creative talent." Indeed, the federal government has a long history of support for cultural programs, including the establishment of the Smithsonian Institution in 1846, the National Conservatory of Music in 1891, and the National Fine Arts Commission in 1897. With the exception, however, of the Works Progress Administration arts employment projects of the New Deal, the NEA was the first agency to grant money directly to private individuals and institutions to create and present works of art without governmental commissioning or control.

Since 1966, the NEA has awarded more than 95,000 grants, spending more than $\$ 2.6$ billion in federal funds, which have been more than equally 
matched by nonfederal sources. Grants are initially recommended by advisory panels in 17 program areas such as music, dance, architecture, and museums. They are then reviewed by the National Council on the Arts, whose members are appointed by the president with the advice and consent of the Senate. Final decisions are made by the NEA chairman, also a presidential appointee. The chairman cannot approve or disapprove any grant application before receiving the council's recommendation on it. Until the past few years, the chairman rarely overturned a council recommendation.

\section{When Is an Endowment \\ Not an Endowment?}

Since its inception, the NEA has never truly been an "endowment," in any commonly known sense. It has no permanent funds and, as any other federal agency, receives appropriations from Congress covering expenses for the current fiscal year only. Carrying over unspent funds from year to year is prohibited, and all grant awards, including those meant to be multiyear in nature, carry a disclaimer that they are subject to the availability of appropriations. By contrast, the Smithsonian Institution and the $\mathrm{Na}$ tional Gallery of Art, both established by private gift and both aggressively engaged in private fund raising, have been accorded the right to maintain nonfederal "trust funds." These funds have often been used to pay for programs and acquisitions not authorized by Congress and for hiring key staff members to bypass Civil Service regulations on selection and salary.

Although the NEA is permitted to accept private gifts, it has made no effort to use that power to give itself the leeway to support controversial artistic activities. Instead, the NEA channeled the obligation to secure private funds to the award recipients through its matching grant program. Nevertheless, from the beginning, the NEA encouraged cutting-edge programming and often became the funder of last resort for projects that could not initially get money from private foundations. As Roger Stevens, the NEA's first chairman, replied when asked how the endowment was different from such foundations, "We do more daring things than they can do." The agency frequently excused the small size of many of its grant awards by describing them as "Good Housekeeping Seals" that assured private foundations and corporate donors that it was safe to fund a project and match the federal grant.

The NEA's first years were marked by a continuing increase in appropriations, par-

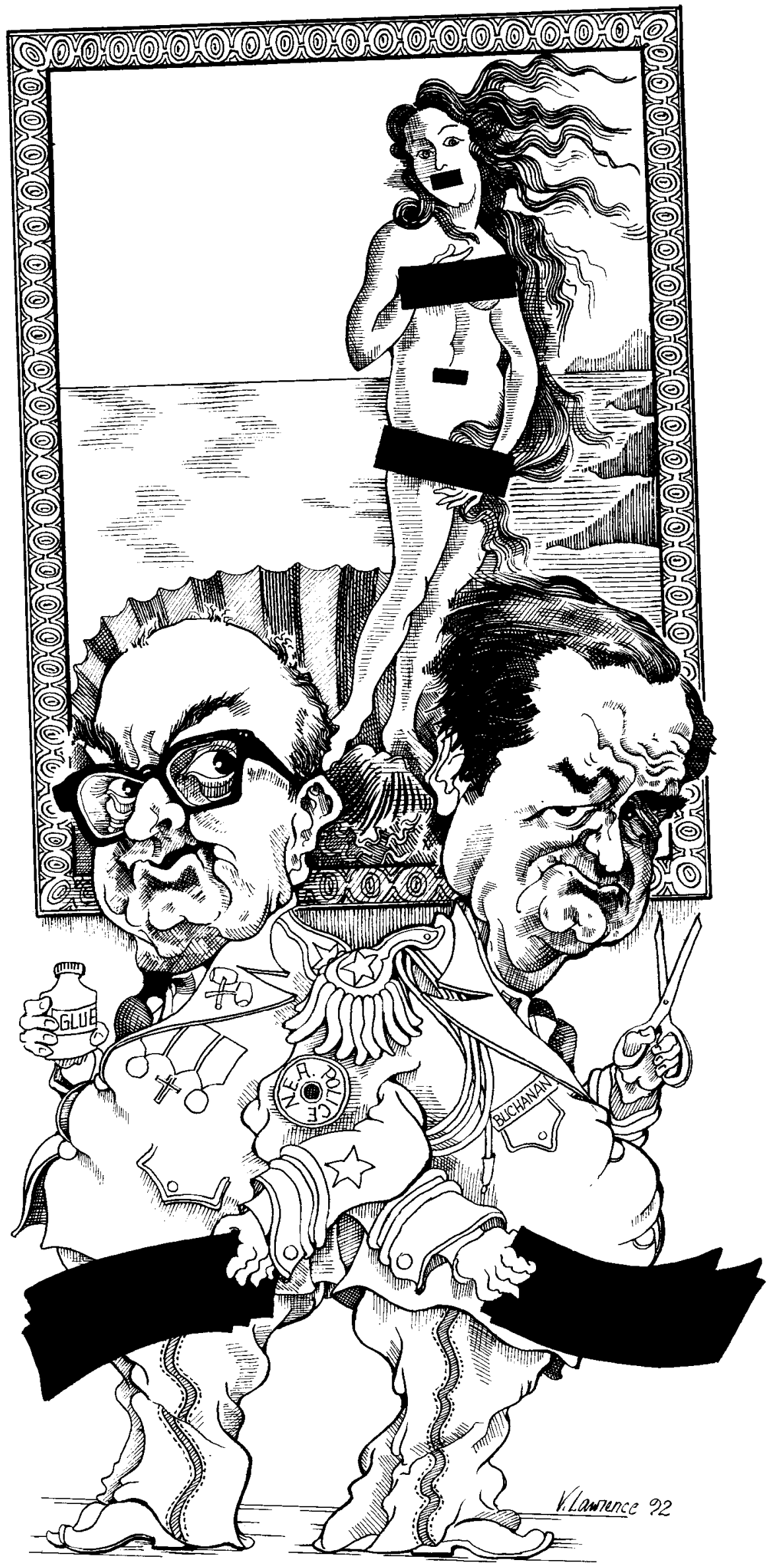


ticularly during the Nixon administration. Funding leveled off during the Carter years. The Reagan administration initially proposed eliminating all funding, but backed off in the face of massive congressional and public opposition. Over the years a number of grants drew controversial attention. Among the most publicized were a $\$ 5,000$ award to Erica Jong in 1973, used in part to support the writing of Fear of Flying, and a 1977 grant of $\$ 6,025$ to LeAnne Wilchusky to throw crepe paper streamers out of an airplane as a "sculpture in space" that "called attention to the higher spirit of mankind."

Although these and several other incidents raised congressional hackles, there were few lasting consequences. A congressional hearing investigating an NEA grant for a poem by Aram Saroyan, whose title and full text were "Lighght," for example, was headed off when Congressman Clarence "Doc" Long (D-Md.) commented, "Mr. Chairman, I don't pretend to know too much about poems, but this is the first one I've been able to memorize." Indeed, a

\section{Legitimate}

questions, upon

which reason-

able people

can differ, exist

concerning the

role of govern-

ment funding

of the arts. prime reason for the NEA's survival has been its strong congressional champions, foremost being Representative Sidney R. Yates (D-Ill.). Yates, as chairman of the House Appropriations Subcommittee on the Department of the Interior and Related Agencies, was responsible not only for the funding of the two endowments, the Smithsonian Institution, and other federal cultural programs, but also for the budgets of almost all Interior Department programs, the fossil fuel programs of the Department of Energy, and the Forest Service programs of the Department of Agriculture. The Appropriations subcommittee chairmen, known collectively in Congress as the "College of Cardinals," wield immense influence among their colleagues. More times than is liked to be admitted, the NEA has benefited from timely assistance to a fish hatchery in North Dakota, a coal mine in Pennsylvania or West Virginia, or a timber cut in Washington state. When a Senate amendment restricting the NEA was removed in exchange for an increase in federal land grazing rights, the phrase "corn for porn" became the instant characterization.

\section{Politics of the Arts}

The second reason for the NEA's survival of occasional congressional displeasure was the political skill of its leaders, who recognized that the arts, with their power to enrich or enrage, were political and needed to be treated as such, but that they also were nonpartisan. Roger Stevens, the first chairman, had been an assistant to President Lyndon Johnson. Nancy Hanks, his successor, was a protegee of Governor and Vice President Nelson Rockefeller. Livingston L. Biddle, Jr., had been an aide to Senator Claiborne Pell and had been instrumental in drafting the NEA's organic legislation. Finally, Frank Hodsoll had been a close associate of James Baker during the 1980 presidential campaign. Each of these chairmen understood the nature of coalition politics and how, for example, a well-publicized and wholly meritorious award to a relatively "safe" recipient such as the Utah Symphony (whose director, the witty and talented Maurice
Abravanal, was a favorite of members of Congress at hearings, and whose senator, Orrin Hatch, was a conservative leader) could be used to assuage the misgivings caused by a second, and equally meritorious, grant to a more controversial New York performance artist. Even Hodsoll, who represented an administration bent on abolishing the NEA, found ways to convince his superiors of the worth of the agency and the impracticality of battling the forces that Yates and his allies had amassed.

This talent for working the system has not been universally considered an asset for the agency. Some critics have charged that the politicization of the NEA, particularly during the Carter administration, led to the current round of troubles. Most of those charges centered on the debate between "populism and elitism" or, more pejoratively, "access versus quality," as if the terms were mutually exclusive. The criticism emerged in particular from the creation of new program areas such as Expansion Arts, Folk Arts, and Advancement Grants, geared toward smaller and younger arts groups, including many minority, ethnic, and more experimental artists and organizations ineligible for NEA grants under existing categories. The debate, however, which has continued over the years, was never really about the artistic merit of the new grants. Rather, as Michael Mooney stated in The Ministry of Culture, the real argument was "over the division of spoils. As long as the "eastern seaboard illuminati' continued to get about the same monies the Nixon administration had dealt out to Lincoln Center, the Metropolitan Opera, and the Boston Symphony, the oligarchs of the East had few objections to new 'populist' fundings for 'folk arts'."

\section{Under Heavy Fire}

John Frohnmayer, an Oregon lawyer who had been a respected chairman of the Oregon Arts Council, never got the hang of the system. As the New York Times described it, "Mr. Frohnmayer, over two and a half years of shifting his position, managed to antagonize artists, arts administrators, and those who took a permissive approach to government support of the arts." Meanwhile, conservatives, who blamed him for the Mapplethorpe grant even though it had been set in motion before he took office and who didn't trust his subsequent vetoes of award recommendations, called for his firing. In only a few months the chairman had secured the wrath of all sides.

Frohnmayer's most disastrous decision came in response to a congressional mandate attached to the fiscal year 1990 NEA appropriations bill. At the instigation of the American Family Association and Senator Jesse Helms (R-N.C.), several attempts, backed by massive direct mail campaigns, were made to restrict the criteria used to judge grant applications, including shopping lists of proscribed topics covering everything from flag "disrespect" to blasphemy to offensiveness to inappropriateness. When it appeared clear that the mood of Congress would require some type of vote for restrictive language, Yates agreed to add a provision to the appropriations bill that essentially tracked the U.S. Supreme Court's 1973 obscenity ruling in Miller 
v. California. The language, which applied to both the NEA and the National Endowment for the Humanities, prohibited projects that "may be considered obscene, including but not limited to, depictions of sadomasochism, homoeroticism, sexual exploitation of children, or individuals engaged in sex acts which, when taken as a whole, do not have serious literary, artistic, political, or scientific value."

Lynne Cheney, chairwoman of the National Endowment for the Humanities, recognized that the prohibition of obscenity was merely a restatement of existing law and a way to let members of Congress vote for decency. She ignored it, and, although the $\mathrm{NEH}$ was in many ways as controversial as its companion agency, there was little fuss. Frohnmayer, however, required grant applicants to swear in advance that no NEA funds would be used "to promote, disseminate, or produce materials which ... may be considered obscene." The response was predictable. The NEA returned to the national spotlight as one arts organization after another lined up to denounce publicly the agency's "loyalty oath," in some cases turning back money that had already been awarded. Increasingly, artists who on merit alone had no chance of getting a grant, submitted deliberately outrageous projects, calling press conferences daring the NEA to turn them down. Frohnmayer's subsequent proposal, "obscenity boards" for judging a project's compliance with the grantee's sworn oath, lost him all remaining credibility with the arts community. Opponents of the agency, incensed by the publicity surrounding the artists, escalated their own attacks. The Bush administration, watching as the endowment lurched from one embarrassment to another, hesitated to fire Frohnmayer. Finally, the Buchanan attack during the New Hampshire primary moved the president to act.

The clamor had so overwhelmed the purposes of the NEA that, in a much noted telecast of This Week with David Brinkley, Brinkley, along with George Will, Cokie Roberts, and Sam Donaldson, a wide sample of Washington conventional wisdom, all agreed it was time for the NEA to be put out of its misery and out of business.

Instead, the new "safe" NEA has been born, committed to the support of inoffensive programming. The premise of the incubator for "more daring things" than the private sector will risk appears ended. In its place is another money tree for mainstream works of artists and organizations. While this mission may keep the agency going for the short term, it leaves the NEA without any root system to keep it standing when the next controversy blows over it.

Congressman Yates has noted that "The glory of the endowment was that you didn't have the Government judging applicants; they were judged by their fellow artists. If [Radice] changes that . . . it will be difficult to get the best people to serve on the panels." As of this writing, several advisory panels have indeed resigned en masse. Stephen Sondheim turned down the 1992 National Medal of Arts award administered by NEA, stating that to accept an award from the endowment would "be an act of the utmost hypocrisy." Next
Wallace Stegner turned down the medal, stating that "support is meaningless, even harmful, if it restricts the imaginative freedom of those to whom it is given." And a new series of grantees are turning back awards.

\section{It's Time to Rethink the NEA}

The chance to restructure the NEA will come in 1993 as Congress takes up the agency's reauthorization and President Clinton appoints a new NEA chairman. (The huge congressional turnover in the wake of the November 3 elections will also provide a new tone to the debates.) Among the recommendations that should be considered is creating a true endowment fund, either based on private donations or a one-time federal grant, to be used, as the Smithsonian Trust Fund is, to provide support that is not directly dependent on appropriations. The statutory role of the National Council on the Arts should also be strengthened, providing for a supermajority override of vetoes by the chairman of recommended grants. The issue of content restrictions on arts grants also needs to be put to rest, for court challenges to "indecency" and "appropriateness" standards will not prevent the uncertainty and chilling effect that these vague and ambiguous restrictions will have on the artist attempting to comply with, or the agency trying to administer, such restrictions.

But what ultimately is needed is a reconsideration-nonpartisan, to the extent possible-of the fundamental question of whether the government should nurture the arts in America. Certainly the arts have no right to governmental support. At the same time, historically, the enrichment of mind and spirit associated with the arts has been a relevant and necessary part of the general welfare of the citizens of the world's great civilizations. Before we undertake to restructure the NEA, we should be sure what role we want the federal government to play in supporting the arts in this country.

Conducting a serious discussion of the matter will not be easy in the current atmosphere. Despite Acting Chairwoman Radice's efforts to placate Senator Helms and his followers, the NEA's value as a bogeyman for right-wing fundraisers has grown to such levels that there is little motivation for them to end the turmoil. And instead of attempting to turn down the heat on this debate, many supporters of the NEA have seized on similar tactics, accepting the Helms premise that arts funding is a question of morality rather than philosophy. This is a serious mistake. Legitimate questions, upon which reasonable people can differ, exist concerning the role of government funding of the arts. But when viewpoints are transformed, by either side, into questions of morality, there can be no serious debate nor any opportunity for compromise.

It is the nature of art to stimulate, to exhilarate, to exasperate, and sometimes to offend-sometimes all at the same time. The great strength of the National Endowment for the Arts has been the underlying premise that not only were Americans not fearful of the clash of ideas and emotions through the arts, but that we welcomed and encouraged such ferment.

The arts cannot be saved by making them "safe."
But when view-

points are trans-

formed into

questions of

morality, there

can be no serious

debate nor any

opportunity for

compromise. 